\title{
PCB-contamination in a school building indoors
}

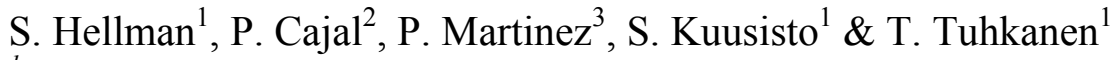 \\ ${ }^{1}$ Department of Chemistry and Biotechnology, \\ Tampere University of Technology, Finland \\ ${ }^{2}$ Universitat Politècnica de Catalunya, Spain \\ ${ }^{3}$ University of Zaragoza, Spain
}

\begin{abstract}
Today substantial amounts of PCB still remain in buildings. PCB is found to be used in different building materials as a plasticizer, e.g. in paints and elastic sealing materials. PCB was used in building materials especially in 1960s but also in the late 1950s and early 1970s. The purpose of the study was firstly to find and to analyze PCBs used in paints in Finnish buildings indoors. The question of the amount of hazardous materials in buildings was approached by a case study in a basement of a school building containing PCB-paint. After analyses the purpose was to remove the PCB-paint and to see what issues there are to be concerned about once the PCB-paint is mechanically removed. At first the original PCB concentrations were analyzed. The greyish floor paint contained PCBs of about $8751 \mathrm{mg} / \mathrm{kg}$. The red paint in walls had concentrations of $23 \mathrm{mg} / \mathrm{kg}$. Since the wall concentration was low, there was no need to remove that mechanically. Renovation of the room was performed as the floor paint was removed. Since sandblasting creates a lot of dust, other methods were applied. The floor paint was removed by grinding. After the removal of the floor paint, all of the surfaces in a room were washed with detergent water. The PCB concentrations were analyzed from wipe samples taken after the paint removal prior to washing and again after the washing. The results show that by removing the floor paint and by washing all the surfaces the concentrations in the room were reduced but PCBs were not totally removed. After grinding and washing, the floor had PCB concentration of about $4019 \mathrm{mg} / \mathrm{kg}$. The results show significant PCB-concentrations still after the paint itself had been removed. It was calculated that originally about $118 \mathrm{~g}$ of pure PCB was present in floor paint
\end{abstract}


in a room of $12 \mathrm{~m}^{2}$. After removal of the floor paint, the total PCB still present in the room was about $58 \mathrm{~g}$. By grinding most of the visible paint, the total reduction of PCBs was about $52 \%$.

Keywords: PCB, paint, renovation, hazardous waste.

\section{Introduction}

Polychlorinated biphenyls (PCBs) are a class of Persistent Organic Pollutants (POPs) that are highly toxic to humans and wildlife, remain intact in the environment for long periods, and accumulate in the fatty tissue of living organisms. PCBs are transported through air, water and migratory species across international boundaries and deposited far from their place of release, where they accumulate in terrestrial and aquatic ecosystems. [1] PCBs can cause damage wherever they travel.

Commercial production of technical mixtures of PCBs with different degree of chlorination started in 1929. PCBs were soon used in various purposes; in closed systems in industrial applications such as heat exchange fluids in electrical transformers and capacitors (liquid PCBs) but also in various open applications such as softeners or additives in paints, sealants and varnishes (nonliquid PCBs). The amount of PCBs produced worldwide 1929-1977 is estimated to be about 1.5 million metric tons [2]. The serious risks associated with PCBs were noticed about 40 years ago when Jensen [3] detected PCBs in pike in Sweden. It became evident that PCBs are not safe to use, their nature was understood and the use began to be restricted. Even though the production of PCBs was stopped over 30 years ago, PCBs continue to be detected in environmental samples and in built environment around the world. PCBs still in use act as passive $\mathrm{PCB}$ reservoirs.

In Finland PCBs can be found in buildings constructed between late 1950s to mid 1970s. Based on our earlier studies we know that PCBs used in building materials are present in external wall sealants, in soil in the vicinity of buildings $[4,5]$ and in indoor paints [6]. The use of PCBs in new building materials was banned in 1989 [7]. Estimates of the volume of PCBs in sealants in Finland vary from $130 \mathrm{t}$ to $270 \mathrm{t}$ [8]. The amount of PCBs used in paints and varnishes is approximately six times of the amount of PCBs used in sealants [9].

\section{Materials and methods}

\subsection{Site description}

As a case study of indoor paint and its removal, a room in a school basement was investigated more closely. The dimensions of the room were $3.7 \mathrm{~m}, 3.3 \mathrm{~m}$ and $2.1 \mathrm{~m}$ as length, width and height respectively. The concrete floor was covered with a greyish blue paint layer. The walls were painted with red paint. The roof was greyish white. There were no windows in the room and only one doorway. 


\subsection{Sample collection}

Floor, walls and roof were sampled. The wipe samples were taken as a clean cotton tissue was moisturized with $10 \mathrm{ml}$ of ethanol and $20 \mathrm{~cm} \times 20 \mathrm{~cm}$ areas were wiped twice. Cotton tissues were sealed in glass tubes [10].

The paint samples were taken by scratching the surfaces with a sterilized scalpel. The scalpel was cleaned with ethanol after each sample. The paint samples were kept in glass tubes. The paint residual samples were taken from the vacuum cleaner bag. Also a dust sample from the floor was taken as the floor was swept.

The water solution used to clean the surfaces was stored in buckets for analysis. The sponges used in cleaning were stored in plastic bags for further analysis as well.

\subsection{Extraction of samples}

The method US EPA 3550 (ultrasonic extraction) was used for the extraction of all the samples. The samples were extracted in an ultrasonic bath and then collected with MQ water. Internal standards in samples, blank samples and calibration mixtures together with blank samples and PCB technical mixtures were used as quality control in the analysis.

Cotton samples were extracted with hexane and acetone $(4: 1)$ in an ultrasonic bath (1h) using 2,4,6-trichlorobiphenyl (PCB \#30) as an internal standard. For wipe samples PCB \#209 was added as a surrogate. The extraction procedure was repeated twice. The extracts were collected and washed with MQ water twice. The water phase was extracted with hexane. The collected hexane phase was evaporated (1-2 ml) under nitrogen flow and washed with concentrated sulphuric acid (1-2 ml). It was extracted and evaporated to complete dryness. The internal standard (PCB\#30) was added after the extraction procedure.

Paint samples were extracted with hexane and acetone in a ratio of $1: 1$. Paint samples were mixed with surrogate $\left(2,2^{\prime}, 3,3^{\prime}, 4,4^{\prime}, 5,5^{\prime}, 6,6^{\prime}\right.$-decachlorobyphenyl; PCB \#209) and extracted in an ultrasonic bath (1h). The extracts were collected and washed with MQ water. The extraction with water was repeated twice. The water phase was extracted with hexane. The collected hexane phase was evaporated $(1-2 \mathrm{ml})$ under nitrogen flow and washed with concentrated sulphuric acid (1-2 ml) and then it was extracted and evaporated to complete dryness. The internal standard (2,4,6-trichlorobiphenyl; PCB \#30) was added after the extraction procedure.

The paint residuals extraction procedure was similar to that of paint samples but the wash with concentrated sulphuric acid was repeated three times. To determine the PCB concentration in water samples an extraction with hexane was performed. $35 \mathrm{ml}$ of water was mixed with hexane $(2 \mathrm{ml})$ and extracted in an ultrasonic bath $(30 \mathrm{~min})$. The extracts were collected and $0.25 \mathrm{~g}$ of $\mathrm{NaSO}_{2}$ was added to remove the rest of the water. Then it was filtered through a $0.2 \mu \mathrm{m}$ nylon membrane (ACRODISC ${ }^{\circledR}$ ) with a $13 \mathrm{~mm}$ syringe. The collected hexane was washed with concentrated sulphuric acid (1-2 ml) and extracted and evaporated to complete dryness. The internal standard (PCB \#30) was added 
after the extraction procedure. The sponges were extracted with the same procedure as wipe samples as described in earlier section.

\subsection{PCB analysis}

PCBs were determined according to the method of US EPA 8082A by using Agilent Technologies gas chromatograph (6890) with a mass selective detector (5972). HP-5MS capillary column (30 m long, $250 \mu \mathrm{m}$ internal diameter and $0.25 \mu \mathrm{m}$ of film thickness) was used with helium as a carrier gas.

The GC-MSD temperature program started at the temperature $80^{\circ} \mathrm{C}$, was held for 1 minute and increased to $150^{\circ} \mathrm{C}$ at $30^{\circ} \mathrm{C} / \mathrm{min}$, to $250^{\circ} \mathrm{C}$ at $4{ }^{\circ} \mathrm{C} / \mathrm{min}$ and to $300^{\circ} \mathrm{C}$ at $10^{\circ} \mathrm{C} / \mathrm{min}$. The velocity of the carrier gas was $1 \mathrm{ml} / \mathrm{min}$. The detection limit was $0.25 \mathrm{mg} / \mathrm{l}$ and the coefficient of variation for GC-MSD method was $3.8 \%$. Aroclor 1260 concentrations were measured as an area of the total ion chromatogram (TIC) from retention time of PCB \#95 to retention time of PCB \#205 [11]. Aroclor 1260, PCB \#30 and PCB \#209 were used as external, internal and surrogate standards, respectively. For the GC-MSD method, Aroclor 1260 contaminated surface recovery averaged was $77.9 \%$ [12].

\subsection{Paint removal and decontamination of the surfaces}

The surfaces of the room were washed with a detergent solution $(0.5 \%)$. The concrete floor paint was removed by grinding. The grinding machine had a high speed, an engine of $1100 \mathrm{~W}$, a disk size of $17^{\prime \prime} / 430 \mathrm{~mm}$, a rotation speed of 400 rpm and a weight of $30 \mathrm{~kg}$. An industrial vacuum cleaner was attached to the grinding device. The vacuum cleaner used during the paint removal was equipped with a HEPA filter.

After vacuuming, the surfaces were washed twice with detergent solution. Wipe and paint samples were taken from the surfaces before paint removal, after paint removal prior washing and after the dust had been removed by vacuumcleaner and washing. The total removal of PCBs was calculated.

\section{Results and discussion}

\subsection{Different phases of the work}

The separate phases of the work in the room chronological order were: sampling before the first surfactant washing, the first washing, sampling after the first washing, sampling before grinding (machine), mechanical paint removal (grinding machine), sampling after the grinding, second washing and sampling after the second washing.

\subsection{Initial situation and first washing}

The PCB concentration in floor paint was $8751 \mathrm{mg} / \mathrm{kg}$ and in the wall paint 23 $\mathrm{mg} / \mathrm{kg}$. Wipe samples were taken to find out the initial situation on the surfaces. Wipe samples taken from the wall, floor and roof showed that all the surfaces 
were contaminated with PCBs in the initial situation (Table 1). After the first washing, the average PCB concentrations on the surfaces remained almost the same.

Table 1: Wiped sample results $\left(\mu \mathrm{g} / \mathrm{m}^{2}\right)$ before first washing.

\begin{tabular}{|c|c|c|c|}
\hline & $\min$ & average & $\max$ \\
\hline Floor & 1118 & 6339 & 11559 \\
\hline Walls & 200 & 282 & 363 \\
\hline Roof & 71 & 71 & 71 \\
\hline
\end{tabular}

\subsection{Before and after mechanical paint removal}

Wipe samples were taken before using the mechanical device. The floor paint was removed by grinding (machine characteristics are described in the section 2.5.) and the sampling was repeated. A wipe sample taken from the wall before paint removal showed a concentration of $650 \mu \mathrm{g} / \mathrm{m}^{2}$. The floor and the roof were not analyzed. After the mechanical paint removal the PCB concentrations taken by wiping were $1341 \mu \mathrm{g} / \mathrm{m}^{2}$ on the floor, $859 \mu \mathrm{g} / \mathrm{m}^{2}$ on the walls and $208 \mu \mathrm{g} / \mathrm{m}^{2}$ on the roof.

After the mechanical paint removal, walls and roof surfaces increased their PCB concentrations. This was due to the dust produced by the machine. The vacuum cleaner was not able to suck completely all of the dust produced.

Floor concrete results reinforced the earlier result that PCBs in the paint could migrate into the concrete. According to Sundahl et al. [13] the concrete close to the sealant was contaminated by PCBs but the concentrations dropped quickly with the distance from the joint. It was suggested that a few $\mathrm{mm}$ of the concrete should be grinded in order to get rid of the PCBs. It was reported also in Finland that in prefabricated houses PCBs were found in concrete next to PCBcontaining sealants [14].

\subsection{Wiped samples}

The final results show a decrease in PCB concentrations but the work done is not enough for total removal of PCBs. It is shown in table 2 that especially the

Table 2: Wiped samples (after second washing with detergent solution) $\left(\mu \mathrm{g} / \mathrm{m}^{2}\right)$.

\begin{tabular}{|c|c|c|c|}
\hline & $\min$ & average & $\max$ \\
\hline Floor & 2003 & 3064 & 4909 \\
\hline Walls & 248 & 248 & 248 \\
\hline Roof & 92 & 92 & 92 \\
\hline
\end{tabular}


concentrations on the floor are high but also the concentration on the wall is still over the Finnish Guideline value $\left(100 \mu \mathrm{g} / \mathrm{m}^{2}\right)$.

Table 2 shows that the removal technique applied and followed by detergent washing was able to decrease PCB concentrations in the room. It can be seen that some of the PCBs in the floor paint were transferred to the walls and roof, since the wall and roof reduction was negative. The dust produced was not collected completely. The total reduction on the surfaces was $71 \%$. The wipe samples mass balance does not show the real amount of PCBs but the amount, which was available in dust attached to the surfaces.

\subsection{Paint and paint residual samples}

The final PCB concentration in the floor (after paint removal and washing) was $4019 \mathrm{mg} / \mathrm{kg}$. The concentration in wall paint was $34.5 \mathrm{mg} / \mathrm{kg}$ and in roof paint $59.9 \mathrm{mg} / \mathrm{kg}$. The PCB concentrations in wall and roof paints were low, which indicates secondary contamination, not the initial PCB compounds in the paint matrix. With applied techniques (grinding and washing) a reduction of PCB concentration in all the surfaces, and especially on the floor, was achieved. Only by grinding it was not possible to remove all of the floor paint, which is the reason for the high concentrations also in the final situation. Also the fact that PCBs migrate into the concrete reinforced with this result. The total amount of PCBs in the paint residuals taken from the vacuum cleaner bag was about $0.43 \%$ as is shown in Table 3 below. The PCB concentration in paint residuals was $4225 \mathrm{mg} / \mathrm{kg}$.

Table 3: $\quad$ PCBs in the paint residuals.

\begin{tabular}{|c|c|}
\hline Paint residuals conc. & $4225 \mathrm{mg} / \mathrm{kg}$ \\
\hline Total weight of paint residuals & $1.88 \mathrm{~kg}$ \\
\hline PCB in paint residuals & $7953.2 \mathrm{mg}$ \\
\hline PCB in the paint residuals & $0.43 \%$ \\
\hline
\end{tabular}

\section{6 $\mathrm{PCB}$ reduction in the room}

At the beginning, the total amount of PCBs in painted surfaces in the room was about $118 \mathrm{~g}$ (based on the surface areas, the paint layer thickness $1 \mathrm{~mm}$ and the

Table 4: $\quad$ The situation before paint removal and washing.

\begin{tabular}{|c|c|c|c|}
\hline & area, $\mathrm{m}^{2}$ & conc., $\mathrm{mg} / \mathrm{kg}$ & total, $\mathrm{g}$ \\
\hline walls & 27.3 & 23 & 0.7 \\
\hline roof & 12.1 & 59.9 & 0.8 \\
\hline floor & 12.1 & 8751 & 116.6 \\
\hline
\end{tabular}


paint layer density $1.1 \mathrm{~kg} / \mathrm{l})$ as shown in Table 4 . The most of the PCB was in floor paint (116.6 g).

After the paint removal and washing the amount of PCBs in the room was about $58 \mathrm{~g}$ (Table 5). The reduction of PCBs in the floor was about 52\%. The PCBs were not removed from the walls but the concentration was increased due to the dust generated during the paint removal. The PCB concentration of the paint residuals were above the hazardous waste limit value of $50 \mathrm{mg} / \mathrm{kg}$ and were considered as hazardous waste.

Table 5: $\quad$ The situation after the paint removal and washing.

\begin{tabular}{|c|c|c|c|}
\hline & area & concentration & total \\
\hline & $\mathrm{m}^{2}$ & $\mathrm{mg} / \mathrm{kg}$ & $\mathrm{g}$ \\
\hline walls & 27.3 & 35 & 1 \\
\hline roof & 12.1 & 59.9 & 0.8 \\
\hline floor & 12.1 & 4225 & 56.2 \\
\hline
\end{tabular}

The detergent solution applied on the surfaces and water solution used to rinse the surfaces, were stored and analyzed after the first and second washing. In the first washing, PCBs were present in the detergent solution $(0.07 \mathrm{mg} / \mathrm{l})$. In the second washing, both water solutions were analyzed together and no PCBs were detected. Since PCBs are not soluble to water, it was assumed that the PCBs detected were attached to particles in the detergent solution.

The sponges used in washing were also analyzed. The PCB concentration was higher in floor sponge $(821 \mathrm{mg} / \mathrm{kg})$ than in wall and roof sponges $(45 \mathrm{mg} / \mathrm{kg}$ average). The total amount of PCBs in the sponges used was $56 \mathrm{mg}(0.05 \%)$.

\section{Conclusions}

These results from our earlier studies and from this case study show that PCBs have been added to various paints, which have been applied in various types of Finnish buildings, mostly indoors and on floors. In Finland there is no legislation that especially requires testing old paints before renovation or demolition of buildings. Some recommendations are given. The results show that construction companies need to be aware of the toxic chemicals involved. The safety requirements during construction work should be strict.

The question about hazardous demolition waste is important. This study suggests that demolition waste from buildings built and painted in late 1950s to early 1970s may contain significant amounts of PCB paints. If present, PCB concentrations in paints will exceed the given limit value $50 \mathrm{mg} / \mathrm{kg}$ for hazardous waste and should be treated as hazardous waste.

The question of investigating the building before renovation work is a question of money. When limited amount of samples is taken, it is important that the sampling is done properly. Based on our earlier studies and this case study it can be stated as follows: soil is to be sampled in Southern side of a building, 
sealants from external walls are to be sampled from Northern side of a building and if PCB paints are possibly present, floor paints are a common source of PCBs and need to be studied.

\section{Acknowledgements}

This work was supported by the Finnish Graduate School in Environmental Science and Technology (EnSTe).

\section{References}

[1] Gjessing, E.T., Steiro, C., Becher, G. \& Christy, A., Reduced analytical availability of polychlorinated biphenyls (PCB's) in colored surface water. Chemosphere, 10, 2006.

[2] Breivik, K., A. Sweetman, J.M. Pacyna \& Jones K.C., Towards a global historical emission inventory for selected PCB congeners - a mass balance approach 1. Global production and consumption. The Science of the Total Environment, 290, pp. 181-198, 2002.

[3] Jensen, S., Report of new chemical hazard. New Scientist, 32, p. 612, 1966.

[4] Hellman, S. \& Puhakka, J., Polychlorinated Biphenyl (PCB) contamination of apartment building and its surroundings by construction block sealants. Geological Survey of Finland, Special Paper, 32, pp. 123-127, 2001.

[5] Priha, E., Hellman, S. \& Sorvari, J., PCB contamination from polysulphide sealants in residential areas -exposure and risk assessment. Chemosphere, 59, pp. 537-543, 2005.

[6] Tuhkanen T., Kuusisto, S., Lindroos, O., Palukka, T., Hellman, S., Priha E., \& Rantio, T., PCB-yhdisteet rakennuksissa ja niiden saneeraamisen aiheuttamien työhygieenisten riskien vähentäminen. Tampere University of Technology. Institute of Environmental Engineering and Biotechnology, 2007, Report 22.

[7] VNp, 1071/1989. Decision of the Council of State 1071/1989. Government decision on restricting the use of PCBs and PCTs. Ministry of Environment, Finland.

[8] Pentti, M. \& Haukijärvi, M., Betonijulkisivujen saumausten suunnittelu ja laadunvarmistus. Tampereen teknillinen korkeakoulu, Talonrakennustekniikka. Publication No. 1000, 2. edition. Tampere, 2000, 88 p. + app.

[9] PCB-committee report, 1983. Committee report 1983:47. Government printing center. Helsinki. Finland.

[10] Kuusisto, S., Lindroos, O., Rantio, T., Priha, E. \& Tuhkanen, T., PCB contaminated dust on indoor surfaces - Health risks and acceptable surface concentrations in residential and occupational settings. Chemosphere, 67, pp. $1194-1201,2007$.

[11] Schulz, D.E., Petrick, G., \& Dulnker, J.C., Complete characterization of polychlorinated biphenyl congeners in commercial Aroclor and Clophen mixtures by multidimensional Gas Chromatography - Electron Capture 
Detector. Environmental Science and Technology, 23(7), pp. 852 - 859, 1989.

[12] Cajal, P., 2007. Fenton treatment of PCB-contaminated surfaces. Master of Science Thesis, Institute of Environmental Engineering and Biotechnology, Tampere University of Technology.

[13] Sundahl, M., Sikander, E., Ek-Olausso, B., Hjorthage, A., Rosell, L. \& Tornevall, M., Determinations of PCB within a project to develop cleanup methods for PCB-containing plastic sealant used in outdoor joints between concrete blocks in buildings. Journal of Environmental Monitoring, 1, pp. $393-387,1999$.

[14] Pyy, V., \& Lyly, O., PCB elementtitalojen saumausmassoissa ja pihojen maaperässä [PCB in apartment building sealants and soil]. Summary in English. Helsinki City Environment Centre, Helsinki, Finland, 25 p. + app., 1998. 